\title{
Measurement of serum $\mathrm{C}$ reactive protein concentration after bone marrow transplantation for leukaemia
}

\author{
IF ROWE,${ }^{*}$ AM WORSLEY, $\dagger$ P DONNELLY $\ddagger$ D CATOVSKY,$\dagger$ JM GOLDMAN,$\dagger$ \\ DAG GALTON, $\dagger$ MB PEPYS*
}

From the *Immunological Medicine Unit, Department of Medicine, the $†$ Medical Research Council Leukaemia Unit, and the $\ddagger$ Department of Bacteriology, Royal Postgraduate Medical School, Hammersmith Hospital, Du Cane Road, London W12 OHS

SUMMARY $C$ reactive protein concentration was measured serially in 19 patients with leukaemia after bone marrow transplantation. Six episodes of graft versus host disease occurred in the presence of fever but with no evidence of infection, and these were associated with $C$ reactive protein concentrations as high as $200 \mathrm{mg} / \mathrm{l}$. C reactive protein values were also increased in 12 febrile episodes associated with infection, in seven of which graft versus host disease was also present. $\mathrm{C}$ reactive protein concentrations are of no value in differentiating infection from graft versus host disease, but in both cases they may be useful as an objective index of response to appropriate treatment.

The clinical management of patients after allogeneic bone marrow transplantation is often complicated. Patients frequently develop clinical signs of acute graft versus host disease in the early days of marrow engraftment, a time when they are also severely neutropenic.' One of the first signs of the disease is an isolated fever and it can be extremely difficult to assess clinically whether the fever reflects graft versus host disease, infection, or both.

$C$ reactive protein is the classical acute phase reactant, the serum concentration of which rises by up to several thousand fold after most forms of tissue damage, infection, inflammation, and malignant neoplasia. ${ }^{2-4}$ Recent studies have shown that in patients who are neutropenic after treatment of leukaemia the serum $C$ reactive protein concentration increases substantially in association with clinically or microbiologically documented episodes of infection. ${ }^{5-7}$ The persistence of a raised $\mathrm{C}$ reactive protein concentration correlates with continuing infection. In contrast, the leukaemic process per se, or its treatment, is associated with only a small, if any, rise in $\mathrm{C}$ reactive protein concentration..$^{5-7}$

The aim of the present study was to determine whether the $C$ reactive protein concentration was

Accepted for publication 24 November 1983 increased in patients with graft versus host disease and to assess the clinical value of serial $C$ reactive protein measurements in patients after bone marrow transplantation.

\section{Patients and methods}

Nineteen patients with leukaemia underwent intensive chemotherapy and total body irradiation and then received bone marrow harvested from HLA identical, mixed lymphocyte reaction unreactive siblings (Table). Patients were nursed in single cubicles with "reverse barrier" precautions against infection. Cotrimoxazole and amphotericin B were given orally as routine antibacterial and antifungal prophylaxis. Cyclosporin was taken orally each day

Disease status of patients studied

\begin{tabular}{lc}
\hline Disease & $\begin{array}{l}\text { No of } \\
\text { patients }\end{array}$ \\
\hline $\begin{array}{l}\text { Acute myeloid leukaemia in first complete } \\
\text { remission }\end{array}$ & 1 \\
$\begin{array}{l}\text { Acute myeloid leukaemia in second complete } \\
\text { remission }\end{array}$ & 1 \\
$\begin{array}{l}\text { Acute megakaryoblastic leukaemia in first complete } \\
\text { remission }\end{array}$ & 1 \\
$\begin{array}{l}\text { Chronic granulocytic leukaemia in chronic phase } \\
\text { Chronic granulocytic leukaemia in accelerated phase }\end{array}$ & 2 \\
Total & 19 \\
\hline
\end{tabular}


in the period after transplant for prophylaxis against graft versus host disease.

A fever was defined as a body temperature of $38^{\circ} \mathrm{C}$ or greater which persisted for $2 \mathrm{~h}$ or longer. The end of a febrile episode was defined as the time when the temperature had remained at or below $37^{\circ} \mathrm{C}$ for $24 \mathrm{~h}$. Documented infections were those in which it was possible to identify the causative organism, isolated either from a clinically defined site of infection or from blood cultures. In one case a febrile episode was designated as being due to viral infection because of clear localising signs and response to antiviral chemotherapy despite negative viral cultures.

Graft versus host disease was diagnosed clinically by the documentation of rash and severe diarrhoea or liver function abnormalities or both, according to the criteria of the Seattle Bone Marrow Transplantation Group.' Whenever possible the disease was confirmed histologically in skin biopsy specimens.

Venous blood was taken for $\mathrm{C}$ reactive protein estimation on two or three occasions in the week before transplant, then daily from the day of transplant until the patient was no longer neutropenic (neutrophils $>1 \times 10^{9} / 1$ ), and thereafter whenever practicable, until the patient was discharged from hospital. Serum was stored at $-20^{\circ} \mathrm{C}$ and assayed for $\mathrm{C}$ reactive protein by electroimmunoassay as described elsewhere. ${ }^{8}$ The assays were standardised using samples of isolated pure $\mathrm{C}$ reactive protein; the coefficients of variation of replicate samples both within and between assays did not exceed $10 \%$.

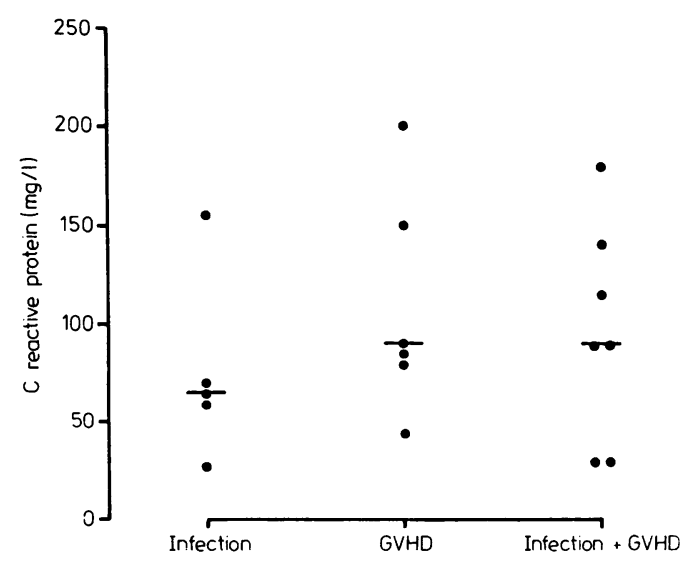

Fig. $1 C$ reactive protein concentration in febrile patients after bone marrow transplantation. Each point represents the maximum $C$ reactive protein value recorded for an individual patient during the episode of fever. Horizontal bars indicate the medians for each group. $(n=18$; one febrile episode was associated with neither graft versus host disease $(G V H D)$ nor infection nor rise in $C$ reactive protein.)

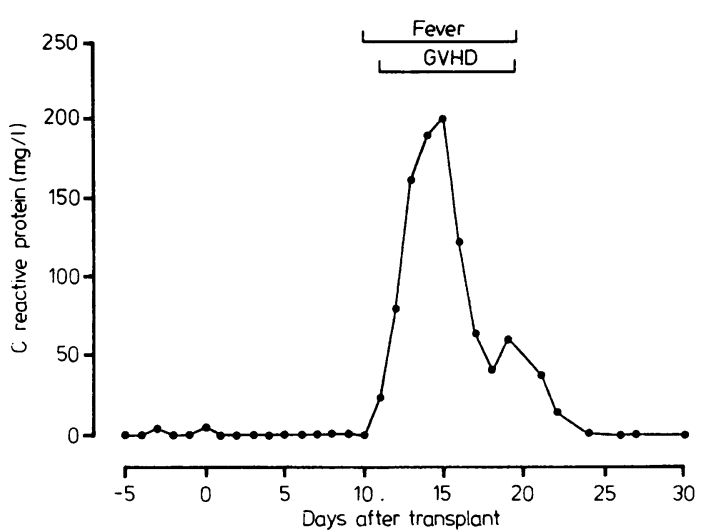

Fig. 2 Serum $C$ reactive protein concentrations after bone marrow transplant in a 22 year old man transplanted for chronic granulocytic leukaemia in accelerated phase. $C$ reactive protein values correlated with fever and graft versus host disease (GVDH), manifested by rash and diarrhoea. Blood and viral cultures were negative.

\section{Results}

During the period after transplant there were 19 episodes of fever occurring in 16 patients, and 18 of these episodes were associated with rises in $\mathrm{C}$ reactive protein concentration. Eleven patients developed symptoms and signs of graft versus host disease, associated with fever and a rise in $\mathrm{C}$ reactive protein. Two of these patients had two separate episodes of fever associated with a rise in $C$ reactive protein concentration and signs of graft versus host disease. Of this total of 13 episodes, seven were associated with infection and in six the graft versus host disease occurred alone. $\mathrm{C}$ reactive protein concentrations increased in all febrile patients with graft versus host disease, but there was no significant difference between the median values obtained in the group with concomitant infection and the group in which graft versus host disease occurred alone (Fig. 1). Graft versus host disease occurring in the absence of infection could be associated with $\mathrm{C}$ reactive protein values as high as $200 \mathrm{mg} / \mathrm{l}$ (Fig. 2). Two other patients had a mild transient rash but no fever and no rise in $\mathrm{C}$ reactive protein. One other patient had a late rise in $\mathrm{C}$ reactive protein concentration but no fever, and a few days later after leaving the hospital developed skin graft versus host disease confirmed by biopsy.

Twelve febrile episodes were associated with infection and all cases were associated with increased serum $\mathrm{C}$ reactive protein concentrations (Fig. 1). In six cases there was oral mucositis, and Herpes simplex virus was isolated from mouth 


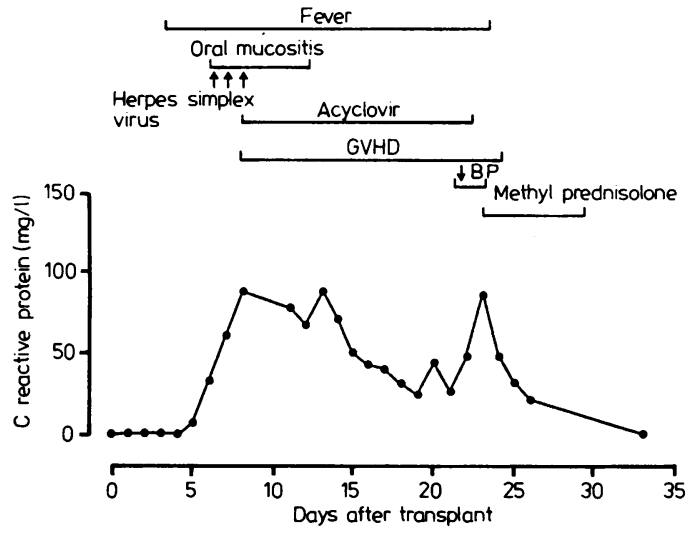

Fig. 3 Serum $C$ reactive protein concentrations after bone marrow transplant in a 40 year old woman transplanted for chronic granulocytic leukaemia in chronic phase. The fever and rise in $C$ reactive protein initially was associated with oral mucositis and positive Herpes simplex cultures (shown by arrows), and the patient was treated with acyclovir. She then developed signs of graft versus host disease $(G V H D)$-initially a rash and diarrhoea and later severe hypotension. She was treated with high dose methyl prednisolone resulting in clinical improvement associated with a fall in $C$ reactive protein concentration.

swabs. A further case of oral mucositis, which clinically appeared to be caused by Herpes simplex despite negative cultures, responded to treatment with intravenous acyclovir. Six febrile episodes were associated with bacterial infections, with isolation from blood cultures of Staphylococcus epidermidis in four patients, Staphylococcus aureus in one patient, and enterobacter in one patient. Seven febrile episodes were associated with concomitant graft versus host disease and infection, and in these patients the $C$ reactive protein concentration was of no use in distinguishing the cause of fever (Fig. 3). In addition, one patient had a rise in $C$ reactive protein concentration associated with a sore throat (from which pseudomonas was isolated) without fever and responded to netilmycin therapy. Two patients had Herpes simplex stomatitis with positive cultures associated with no fever and no rise in $\mathrm{C}$ reactive protein concentration.

\section{Discussion}

In this study all febrile patients with graft versus host disease in the absence of infection had increased serum $C$ reactive protein concentrations, and the concentrations fell as the episodes of graft versus host disease resolved. Some episodes of graft versus host disease are associated with infection, and it is possible that the process of infection precipitates the disease. $C$ reactive protein concentrations did not appear to rise before the onset of fever or other clinical signs of infection or graft versus host disease, so they did not predict clinical problems in the period after transplant. Also, as $\mathrm{C}$ reactive protein concentration rose in both infection and graft versus host disease, it was not useful in distinguishing between these problems. Nevertheless, $C$ reactive protein values did reflect closely the clinical response to appropriate treatment, whether for infection or graft versus host disease.

The prevention and treatment of infection and graft versus host disease are both major problems in bone marrow transplantation. Cyclosporin may prevent graft versus host disease in some patients and alleviate the severity in others. ${ }^{9}$ Episodes of acute severe graft versus host disease are difficult to treat, however, and apart from symptomatic and supportive treatment, high dose methyl prednisolone treatment, with its complications of fluid retention, disordered glucose metabolism, hypertension, and immunosuppression, is necessary. Provided the nonspecific nature of the $C$ reactive protein response is recognised and $C$ reactive protein results are interpreted only in the light of full clinical information about the patients, serial $C$ reactive protein estimations may be useful in this complex situation. Prompt availability of serum $\mathrm{C}$ reactive protein values, measured by the commercially available rapid assay systems (Syva Company, Palo Alto, Ca, USA, or Beckman Instruments, Fullerton, $\mathrm{Ca}$, USA), should provide an objective index of response to treatment both for microbial infection and for graft versus host disease, and thereby contribute to improved patient management.

We thank Mr GS Takhar for technical assistance. This study was supported in part by MRC Programme Grant G979/51 to MBP. IFR is the recipient of a MRC Research Training Fellowship.

\section{References}

' Glucksberg H, Storb R, Fefer A, et al. Clinical manifestation of graft-versus-host disease in human recipients of marrow from HLA-matched sibling donors. Transplantation 1974;18:295304.

${ }^{2}$ Tillett WS, Francis T. Serological reactions in pneumonia with a non-protein somatic fraction of pneumococcus. $J$ Exp Med 1930; 52: 561-71.

${ }^{3}$ Pepys MB. C-reactive protein fifty years on. Lancet 1981;i: 653-7.

4 Pepys MB, Baltz ML. Acute phase proteins with special reference to $\mathrm{C}$-reactive protein and related proteins (pentaxins) and serum amyloid A protein. Adv Immunol 1983;34:141212.

${ }^{5}$ Schofield KP, Voulgari F, Gozzard DI, Leyland MJ, Beeching $\mathrm{NJ}$, Stuart J. C-reactive protein concentration as a guide to 
antibiotic therapy in acute leukaemia. J Clin Pathol 1982;35: 866-9.

- Williams M, McCallum J, Dick HM. The detection of infection in leukaemia by serial measurement of $\mathrm{C}$-reactive protein. $J$ Infection 1982;4:139-47.

' Starke ID, de Beer FC, Donnelly P, et al. Serum C-reactive protein levels in the management of infection in acute leukaemia. Europe J Cancer (in press).

${ }^{8}$ Pepys MB, Dash AC, Markham RE, Thomas HC, Williams BD, Petrie A. Comparative clinical study of protein SAP (amyloid $\mathrm{P}$ component) and C-reactive protein in serum. Clin Exp Immunol 1978;32:119-24.
' Powles RL, Clink HM, Spence D, et al. Cyclosporin A to prevent graft-versus-host disease in man after allogenic bone marrow transplantation. Lancet 1980; i: 327-9.

Requests for reprints to: Dr MB Pepys, Immunological Medicine Unit, Department of Medicine, Royal Postgraduate Medical School, Du Cane Road, London W12 OHS, England. 